\title{
MODERN TREATMENT OF SEVERE "SHRINKAGE OF THE CONJUNCTIVA"*†
}

\author{
BY \\ R. F. TAYLOR \\ Corneo-Plastic Unit, East Grinstead, Surrey
}

COOPER (1858) first described the ocular manifestations of pemphigus. von Kries (1878), working in von Graefe's clinic, described "essential shrinkage of the conjunctiva", and von Graefe (1879) identified the terminal state of pemphigus with essential shrinkage of the conjunctiva. By 1892, when Duane translated Fuchs's textbook into English, the diagnosis of pemphigus conjunctivae was established and three clinical pictures were described:

(1) Lesions of the conjunctiva associated with "pemphigus vulgaris of the skin";

(2) Lesions of the conjunctiva with lesions of the mucous membrane, the skin being healthy;

(3) Conjunctival lesions without lesions elsewhere.

It is now known that the lesions described are not associated with pemphigus vulgaris or any other variety of true pemphigus, but it was not until 1919 that Thost made a plea that "benign mucous membrane pemphigus" be distinguished from other forms of pemphigus. That this was in fact a different disease was established by the later histo-pathological studies of Civatte (1949), confirmed by Lever (1951), which showed that the bullae of benign mucous membrane or ocular pemphigus were subepidermal, whereas those of true pemphigus were intra-epidermal, characterized by acantholysis. In addition, the prognosis for life is vastly different in the two conditions.

Rycroft (1934) further elucidated the picture with a survey of the literature and an account of five cases; these he divided into:

(i) acute forms-occurring between 2 and 35 years.

(ii) chronic forms-occurring between 40 and 70 years.

That the acute forms are almost entirely cases of erythema multiforme exudativum was advanced by Klauder and Cowan (1942) and by Lever and Talbott (1942). This disease was described by Hebra (1866), but has become commonly known as Stevens-Johnson syndrome since the account of two cases with severe ocular manifestations by Stevens and Johnson (1922). In addition to these two conditions, the picture of sub-conjunctival shrinkage can be produced by drug sensitivity, and one such case is included in this paper. Hansen (1950), in describing eight cases, suggested that hypersensitivity to drugs should be suspected in all cases.

* Received for publication July 19, 1965

$\dagger$ Address for Reprints : 187 Macquarie St., Sydney, N.S.W., Australia. 
Klauder and Cowan (1942) classified a further group in which the condition was due to vaccinia, dermatitis herpetiformis, or epidermolysis bullosa dystrophica.

Borrie and Jones (1959) described a case of Sjögren's disease going on to conjunctival shrinkage.

These then are the possible causes of shrinkage of the conjunctiva and the first three are by far the commonest:

(1) Ocular pemphigus or pemphigoid;

(2) Erythema multiforme exudativum;

(3) Drug sensitivity;

(4) Vaccinia;

(5) Dermatitis herpetiformis (that this is so is doubtful according to Sneddon (1961), who suspects that many cases so described were in fact due to ocular pemphigus showing transient generalized bullae);

(6) Epidermolysis bullosa;

(7) Sjögren's syndrome.

\section{Present Investigation}

Sixteen cases which presented at the Corneo-plastic unit, Queen Victoria Hospital, East Grinstead, with conjunctival shrinkage have been analysed with special reference to the following:

(1) Natural history of the disease (including age at onset)

(2) Pathology

(3) Clinical picture

(4) Efficiency of steroids

(5) Comparison between pre- and post-steroid eras

(6) Importance of moisture on the course of the disease

(7) Treatment.

Over the past 12 years, experience in treating these cases has led to several methods being abandoned as useless, and gradually a scheme of treatment has been evolved which appears to be the best possible in the light of present knowledge and resources. The sixteen cases included seven of ocular pemphigus, seven of erythema multiforme, one of drug sensitivity (to phenylbutazone), and one of doubtful aetiology.

It is deemed preferable to present them in tabular form rather than as sixteen case histories (Table, overleaf).

It must be emphasized that these were mainly very severe cases and that most of them were referred for surgery as the only possible means of improvement.

Several of the patients came from abroad and in others the disease had started as long ago as the 1930s. Consequently, it has not been possible in every case to obtain accurate records of the early stages.

\section{Age at Onset}

The average age at onset of the seven cases of erythema multiforme is $7 \frac{1}{2}$ years. This is in keeping with the series of 61 cases reported by Howard (1963), in which the average age was $5 \frac{1}{4}$ years. 
The average age at onset of the seven cases of ocular pemphigus is just over 57 years. This contrasts with the generally accepted statement that ocular pemphigus is a disease of the aged (Sneddon, 1961). In a series of cases collected by Church and Sneddon (1953), the average age was 66, but of these only two became blind. It may be that cases of earlier onset have a poorer ocular prognosis, or it may simply be that the longer the disease exists the worse the prognosis for vision. In either case the disease should be suspected at an earlier age than hitherto. Two of our cases presented in their forties and Case 14 claims that ulceration in the mouth preceded ocular signs by 5 years, but since there is no documentary evidence of this the age at onset is taken to be 51 years.

\section{Clinical Course}

In the cases considered, the natural history of these conditions had been complicated by surgery in many instances, but there are several conclusions to be drawn which are not well appreciated at present.

It has been stressed by several authors that although most cases of erythema multiforme exudativum have no further ocular trouble after the initial acute disease, some manifest late sequelae and progression (Wolff, 1949; Klauder, 1959; Howard, 1963).

In this series Cases 1 and 2 manifested acute episodes 17 and 25 years respectively after the first onset. Case 5 presented with an acute episode in 1959, 5 years after onset. Case 7 manifested exacerbations in June and August, 1958, when ulceration of the conjunctiva was noted; a progression of the fibrous corneal overgrowth was noted in 1960, and in 1961 the left eye perforated, at a time when there had been no surgery during the previous 12 months. Cases 8, 12, and 15 showed no recent activity, but it is important to note that both 8 and 15 reacted to surgery by vascularization and overgrowth of fibrous tissue. In fact all of these cases reacted similarly to excision of tissue.

It is not possible, of course, to stipulate that further episodes are a recurrence of the original pathology, but in these instances trichiasis and, as far as posšible, secondary bacterial infection were ruled out. They mostly responded to extensive steroid therapy, which will be discussed later. The important point is that some cases have further ocular episodes, and also react to surgery involving the conjunctiva by vascularization and overgrowth of fibrous tissue.

\section{Pathology}

Earlier attempts at corneal grafting, and more recently the practice of performing superficial keratectomy, have resulted in a considerable amount of material becoming available for histo-pathological examination. Before considering this, it is worth reviewing the literature.

In the skin, Lever (1951) has shown that the bullae of both ocular pemphigus and erythema multiforme exudativum are sub-epidermal. Church and Sneddon (1953) demonstrated a similar picture and a slight infiltration of eosinophil and neutrophil polymorphs in the adjacent dermis. Lortat-Jacob (1958) described a cellular infiltrate in the underlying 


\begin{tabular}{|c|c|c|c|c|c|c|c|}
\hline \multirow{2}{*}{$\begin{array}{l}\text { Case } \\
\text { No. }\end{array}$} & \multirow[b]{2}{*}{ Sex } & \multicolumn{2}{|c|}{ Age (yrs) } & \multirow[b]{2}{*}{ Details of Onset } & \multirow[b]{2}{*}{ Diagnosis } & \multirow[b]{2}{*}{ Previous Treatment } & \multirow{2}{*}{$\begin{array}{l}\text { Clinical Picture } \\
\text { at Time of Presentation }\end{array}$} \\
\hline & & $\begin{array}{c}\text { At } \\
\text { Onset }\end{array}$ & $\begin{array}{c}\text { At } \\
\text { Presen } \\
\text { tation }\end{array}$ & & & & \\
\hline 1 & $\mathbf{M}$ & $\begin{array}{c}11 \\
(1934)\end{array}$ & $\begin{array}{c}27 \\
(1950)\end{array}$ & $\begin{array}{l}\text { Not known } \\
\text { Pre-steroid }\end{array}$ & $\begin{array}{l}\text { Probably erythema } \\
\text { multiforme } \\
\text { exudativum }\end{array}$ & $\begin{array}{l}\text { Superficial } x \text {-ray } \\
\text { Peritomies and cauterization }\end{array}$ & $\begin{array}{l}\text { Symblepharon and heavy } \\
\text { vascularization conjunctiva } \\
\text { Vascularization and scarring cornea }\end{array}$ \\
\hline 2 & $\mathbf{M}$ & $\begin{array}{c}13 \\
(1926) \\
30 \\
(1943) \\
\text { Recur- } \\
\text { rence }\end{array}$ & $\begin{array}{c}38 \\
(1951)\end{array}$ & $\begin{array}{l}\text { Febrile illness } \\
\text { Blisters } \\
\text { Conjunctivitis } \\
\text { Pre-steroid }\end{array}$ & $\begin{array}{c}\text { Erythema } \\
\text { multiforme } \\
\text { exudativum }\end{array}$ & Not known & $\begin{array}{l}\text { R Symblepharon. Pre-corneal } \\
\text { membrane. No moisture } \\
\text { L Symblepharon. Partial pre-corneal } \\
\text { membrane } \\
\text { Moist }\end{array}$ \\
\hline 3 & $\mathbf{F}$ & $\begin{array}{c}47 \\
(1944)\end{array}$ & $\begin{array}{c}56 \\
(1953)\end{array}$ & $\begin{array}{l}\text { Skin rash for } 1 \mathrm{yr} \\
\text { before eye } \\
\text { involvement } \\
\text { Pre-steroid }\end{array}$ & Ocular pemphigus & Contact lenses (seldom worn) & $\begin{array}{l}\text { Trichiasis upper lids } \\
\text { Symblepharon } \\
\text { Sub-epithelial corneal opacity and } \\
\text { vascularization } \\
\text { Moist } \\
\text { 1958: Schirmer's test: } 16 \mathrm{R}, 6 \mathrm{~L}\end{array}$ \\
\hline 4 & $\mathbf{F}$ & \begin{tabular}{c|}
30 \\
$(1925)$ \\
\end{tabular} & $\begin{array}{c}58 \\
(1953)\end{array}$ & $\begin{array}{l}\text { Hospitalized } \\
\text { Rash on chest } \\
\text { Pre-steroid }\end{array}$ & $\begin{array}{l}\text { ? Erythema } \\
\text { multiforme } \\
\text { exudativum } \\
\text { ? Drug sensitivity }\end{array}$ & Enucleation (L) & $\begin{array}{l}\text { Symblepharon } \\
\text { Corneae covered with thick } \\
\text { vascularized membrane }\end{array}$ \\
\hline 5 & $\mathbf{F}$ & $\begin{array}{c}42 \\
(1944)\end{array}$ & $\begin{array}{c}52 \\
(1954)\end{array}$ & Very gradual & $\begin{array}{l}\text { Probably ocular } \\
\text { pemphigus in } \\
\text { view of slow } \\
\text { onset and } \\
\text { oesophageal } \\
\text { stricture }\end{array}$ & $\begin{array}{l}\text { None for } 1 \text { year } \\
\text { Atropine } \\
\boldsymbol{\beta} \text { plaque irradiation } \\
\text { Contact lenses unsuccessful } \\
\text { Visual acuity good }\end{array}$ & $\begin{array}{l}\text { Symblepharon } \\
\mathbf{R} \text { Perilimbal corneal opacity } \\
\text { Pannus above } \\
\text { Central cornea clear } \\
\text { L Cornea covered with vascularized } \\
\text { membrane } \\
\text { Moist eye (Fig. 4) } \\
\text { Trichiasis } \\
\text { Oesophageal stricture }\end{array}$ \\
\hline 6 & $\mathbf{M}$ & $\begin{array}{c}69 \\
(1952)\end{array}$ & $\begin{array}{c}73 \\
(1956)\end{array}$ & - & Ocular pemphigus & $\begin{array}{l}\text { Local and systemic cortisone } \\
\text { Hydrocortisone drops hourly in } \\
1956 \\
\text { Chloroquine orally }\end{array}$ & $\begin{array}{l}\text { Muco-purulent discharge } \\
\text { Symblepharon } \\
\text { Pre-corneal fibrous tissue } \\
\text { L Corneal ulceration }\end{array}$ \\
\hline 7 & $\mathbf{F}$ & $\begin{array}{c}6 \\
(1955) \\
\end{array}$ & $\begin{array}{c}8 \\
(1957)\end{array}$ & Febrile & $\begin{array}{c}\text { Erythema } \\
\text { multiforme } \\
\text { exudativum }\end{array}$ & $\begin{array}{l}\text { Topical antibiotics and } \\
\text { steroids }\end{array}$ & $\begin{array}{l}\text { L Ankyloblepharon } \\
\text { Cornea covered with fibrotic } \\
\text { membrane } \\
\text { Entropion } \\
\text { R Symblepharon } \\
\text { Corneal opacity lower half }\end{array}$ \\
\hline 8 & $\mathbf{M}$ & $\begin{array}{c}10 \\
(1954)\end{array}$ & $\begin{array}{c}14 \\
(1958)\end{array}$ & - & $\begin{array}{l}\text { Erythema } \\
\text { multiforme }\end{array}$ & $\begin{array}{l}\text { Systemic aureomycin } \\
\text { Antibiotics } \\
\text { Atropine } \\
\text { Cortisone } \\
\text { 1955: Mucous membrane } \\
\text { grafts upper lids } \\
\text { 1955: Lash line moved back by } \\
\text { flap }\end{array}$ & $\begin{array}{l}\text { Precorneal membranes } \\
\text { Xerosis } \\
\text { Entropion } \\
\text { R Cornea thin } \\
\text { In Home for Blind }\end{array}$ \\
\hline 9 & $\mathbf{M}$ & $\begin{array}{c}11 \\
(1954)\end{array}$ & $\begin{array}{c}16 \\
(1959)\end{array}$ & - & $\begin{array}{c}\text { Erythema } \\
\text { multiforme } \\
\text { exudativum }\end{array}$ & $\begin{array}{l}\text { Antibiotics } \\
\text { Cortisone local and systemic } \\
\text { during acute illness }\end{array}$ & $\begin{array}{l}\text { Photophobic } \\
\text { Deficiency of normal lashes } \\
\text { Symblepharon } \\
\mathbf{R} \text { Normal cornea } \\
\mathbf{L} \text { Temporal half of cornea hazy, } \\
\text { pannus 12-3 o'clock }\end{array}$ \\
\hline 10 & $\mathbf{F}$ & $\begin{array}{c}655 \\
(1960)\end{array}$ & $\begin{array}{c}67 \\
(1962)\end{array}$ & - & Ocular pemphigus & $\begin{array}{l}\text { Epilation } \\
\text { Topical cortisone ointment and } \\
\text { antibiotics } \\
\text { Prednisolone } 5 \text { mg. } 4 \text { times } \\
\text { daily. } \\
\text { Left mucous membrane graft }\end{array}$ & $\begin{array}{l}\text { Ankyloblepharon } \\
\text { Pre-corneal membrane } \\
\text { R Moist } \\
\text { L Dry }\end{array}$ \\
\hline
\end{tabular}


Clinical Particulars of Sixteen Severe Cases

\begin{tabular}{|c|c|c|}
\hline Treatment after Presentation & Visual Result & Course of Disease \\
\hline $\begin{array}{l}\text { Lamellar grafts (R2, L1) } \\
\text { Repeated cautery peritomies } \\
\text { Division of symblepharon and superficial } \\
\text { keratectomy (L) } \\
\text { Contact lenses }\end{array}$ & $\begin{array}{l}\text { 1950: R divergent } \\
\text { L } 3 / 60 \\
\text { 1963: L } 6 / 60 \\
\text { N14 } \\
\text { N5 with correction }\end{array}$ & $\begin{array}{l}\text { Oct. 1959: Exacerbation } \\
\text { May 1962: Quiet but reacted to superficial } \\
\text { keratectomy by overgrowth of cornea }\end{array}$ \\
\hline $\begin{array}{l}\text { Lamellar graft (R) in June and September, } 1961 \\
\text { Division of symblepharon (R) } \\
\text { Cautery peritomy (L) } \\
\text { Sealing of puncta } \\
\text { Frequent topical cortisone (hourly when necessary), } \\
\text { and intramuscular cortisone } \\
\text { Now on prednisolone } 5 \text { mg./day }\end{array}$ & $\begin{array}{l}\text { June 1960: Hand movements } \\
\text { With contact lenses R6/36 } \\
\text { L6/24 }\end{array}$ & $\begin{array}{l}\text { Recurrence } 17 \text { years after onset } \\
\text { Grafts became opaque and vascularized } \\
\text { L Quiet since presenting } \\
\text { R Reacted to surgery }\end{array}$ \\
\hline $\begin{array}{l}\text { Penetrating graft }(\mathbf{R}) \text { failed } \\
\text { Lamellar graft }(\mathbf{R}) \text { acquired appearance of } \\
\text { surrounding cornea } \\
\text { Electrolysis } 5 \text { times } \\
\text { Numerous epilations } \\
\text { Sealing of puncta }\end{array}$ & $\begin{array}{l}\mathbf{R} \text { Hand movements } \\
\mathbf{L} \text { Counting fingers } \\
\text { No improvement }\end{array}$ & Quiet since 1959 \\
\hline $\begin{array}{l}\text { Mucous membrane fornix grafts } \\
\text { Lamellar graft (1) } \\
\text { Penetrating graft (3) } \\
\text { Superficial keratectomy (2) with contact lenses } \\
\text { 1953: Course of hourly cortisone drops } \\
\text { 1957: Irradiation } \\
\text { 1961: Extracapsular extraction }\end{array}$ & $\begin{array}{l}\text { R Perception of light } \\
\text { No improvement }\end{array}$ & $\begin{array}{l}\text { Mucous membrane grafts became pemphigoid } \\
\text { Corneal overgrowth with vascularized tissue } \\
\text { Reacted violently to surgery throughout until last } \\
\text { operation in } 1961\end{array}$ \\
\hline $\begin{array}{l}\text { Division of symblepharon (L3) with improvement } \\
\text { Cautery peritomy } \\
\text { Electrolysis } \\
\text { 1954: hourly cortisone (May-July) to cover } \\
\text { symblepharon surgery (L) } \\
\text { 1955: hourly cortisone (May) to relieve } \\
\text { irritability (R) }\end{array}$ & $\begin{array}{l}\text { R } 6 / 5 \\
\text { L Hand movements } \\
\text { No change }\end{array}$ & $\begin{array}{l}\text { R Remained same since } 1954 \text {, apart from episode } \\
\text { of irritability } \\
\text { L Reacted to surgery }\end{array}$ \\
\hline $\begin{array}{l}\text { Superficial keratectomy with insertion of shell (L) } \\
\text { Symblepharon incised, fornices deepened } \\
\text { Contact lenses } \\
\text { Electrolysis } \\
\text { Superficial keratectomy, contact lenses } \\
\text { Intensive steroids }\end{array}$ & $\begin{array}{l}\text { R } 6 / 12 \\
\text { L } 3 / 60 \\
\text { R } 6 / 18 \\
\text { L } 6 / 12 \mathrm{pt} \\
\text { 6/60 } \\
\quad 6 / 9 \text { with contact lenses }\end{array}$ & $\begin{array}{l}\text { Encroachment of pemphigoid tissue on corneae } \\
\text { Still reacting to surgery after } 6 \text { yrs, but dramatic } \\
\text { control achieved with intensive steroids } \\
\text { Patient now deceased }\end{array}$ \\
\hline $\begin{array}{l}\text { Division of symblepharon (L) } \\
\text { Superficial keratectomy and contact lens (L) } \\
\text { Van Milligan mucous membrane graft (L) failed } \\
\text { Contact lens and tarsorrhaphy (L) } \\
15.2 .60 \text { : Further superficial keratectomy (L) } \\
\text { Electrolysis (R) } \\
\text { Strip peritomy (R) }\end{array}$ & $\begin{array}{l}\text { R } 6 / 9 \text { pt. } \\
\text { L Perception of light } \\
\text { R } 6 / 12 \text { Contact lens poorly } \\
\text { tolerated } \\
\text { R } 6 / 24 \text { without contact lens }\end{array}$ & $\begin{array}{l}\text { Recurrences in June and August, } 1958 \\
\text { R Progression with tongue-like growth of tissue } \\
\text { December, } 1960 \\
\text { L Perforated January, } 1961 \\
\text { R Exacerbated October, } 1961 \\
\text { R All episodes contained with intensive steroids }\end{array}$ \\
\hline $\begin{array}{l}\text { Mucous membrane graft lower lid (L) } \\
\text { Superficial keratectomy (L) } \\
\text { Lamellar graft (2-hourly prednisolone) failed (L) } \\
\text { Excision of muscle and wedge of tarsus lower } \\
\text { lid (L) } \\
\text { Streetfield-Snellen operation upper lid (R) } \\
\text { Contact lenses + paroleine }\end{array}$ & $\begin{array}{l}\text { R Perception of light } \\
\text { L Perception of light (better) } \\
\text { (Fig. 1) } \\
\text { L 6/36 with contact lens } \\
\text { (Fig. 2) }\end{array}$ & $\begin{array}{l}\text { L Vascularization, but cornea clearer } \\
\text { L Quiet with contact lens since May, } 1959\end{array}$ \\
\hline $\begin{array}{l}\text { Epilation } \\
\text { Streetfield-Snellen operation upper lid (L) } \\
\text { Contact lenses }\end{array}$ &  & $\begin{array}{l}\text { Recurrence } 1959 \\
\text { L Corneal ulcer with nebula }\end{array}$ \\
\hline $\begin{array}{l}\text { Superficial keratectomy from lid margin to lid } \\
\text { margin } \\
\text { Diathermy of infiltrating vessels } \\
\text { Epilation } \\
\text { Contact lenses }\end{array}$ & $\begin{array}{l}\mathbf{R} \text { Hand movements } \\
\mathbf{L} \text { Counting fingers at } 3 \mathrm{ft} .\end{array}$ & $\begin{array}{l}\text { Vascularization within weeks despite 500r. } \\
\quad \beta \text {-irradiation } \\
\text { Rapid deterioration } 1960-62 \\
\text { Relapse November, } 1962\end{array}$ \\
\hline
\end{tabular}


dermis in which plasma cells often predominate. Gazala (1959) demonstrated excessive cellular infiltration in the upper layers of the sub-conjunctiva and fibrous tissue proliferation beneath an intact epithelium in a case of-ocular pemphigus.

The sections from those cases presented here show in varying degrees (1) epidermoid changes in the epithelium, (2) sub-epithelial granulation tissue, and (3) fibrous proliferation in the conjunctival stroma.

\section{Case Reports}

I. Case 10: $1962-2$ years after onset and still active.

The epithelium is irregularly thickened and epidermoid, and a well-marked stratum granulosum keratinization is present. Basement membrane is absent. Below the epithelium is an oedematous granulation tissue infiltrated by polymorphs, plasma cells, and round cells.

II. Case 1: 1960 - 26 years afer onset and apparently quiet.

There is fibrous proliferation and increased vascularity underlying the epithelium. Some of the vesssels are thrombosed and there is no obvious cellular infiltration present.

Cases of ocular pemphigus and erythema multiforme show no obvious difference other than the presence of perivascular lymphocyte cupping in the latter.

Gazala (1959) stated that "bullous formation is only one aspect of the disease. The actual pathological process seems to be a fibrous tissue proliferation in the sub-epithelial layer". It seems reasonable to assume, however, that both are manifestations of an inflammatory process which takes place in the sub-epithelial layers. 
continued

\begin{tabular}{|c|c|c|}
\hline Treatment after Presentation & Visual Result & Course of Disease \\
\hline $\begin{array}{l}\text { Superficial keratectomy, fornix reconstruction } \\
\text { Contact lenses } \\
\text { Surgery elsewhere: mucous membrane grafts } \\
\text { Transposition parotid duct (L) } \\
\text { October, 1962: Superficial keratectomy (L) } \\
\text { Superficial keratectomy revealed perforation (L) }\end{array}$ & $\begin{array}{l}\mathbf{R}\} \text { Hand movements } \\
\mathbf{L}\} \text { Hovements } \\
\mathbf{R} \text { Hand movem light } \\
\mathbf{L} \text { Perception of }\end{array}$ & $\begin{array}{l}\text { Further contraction of fornices } \\
\text { L perforated } \\
\text { Corneal fibrous tissue } \\
\text { Fornices present, but absent except upper } \\
\text { Probably still active }\end{array}$ \\
\hline $\begin{array}{l}\text { Wedge resection lower lids } \\
\text { Electrolysis of lashes } \\
\text { Contact lenses }\end{array}$ & $\begin{array}{l}\text { R } 2 / 60 \\
\text { L Hand movements } \\
\text { R } 6 / 60 \text {, N8 with contact lens }\end{array}$ & No recent recurrence \\
\hline Contact lenses & $\left.\begin{array}{l}R \\
\mathbf{L} \\
\mathbf{R} \\
\mathbf{L} \\
\mathbf{R} \\
\mathbf{L}\end{array}\right\} \begin{array}{l}\text { Counting fingers } \\
6 / 24 \\
6 / 18 \text { with contact lenses }\end{array}$ & \\
\hline $\begin{array}{l}\text { Superficial keratectomy and lower fornix } \\
\text { reconstruction (L) } \\
\text { Intensive topical steroids } \\
\text { Contact lenses (Fig. 3) }\end{array}$ & $\begin{array}{l}\text { R } 6 / 24 \\
\text { L Hand movements } \\
\text { R } 6 / 24 \\
\left.\begin{array}{l}\text { L } 6 / 18\end{array}\right\} \text { with contact lenses }\end{array}$ & $\begin{array}{l}\text { Lower fornix remained deep } \\
\mathrm{R} \text { unchanged since } 1962 \\
\mathrm{~L} \text { reacted to superficial keratectomy with corneal } \\
\text { overgrowth, but less violently than most }\end{array}$ \\
\hline $\begin{array}{l}\text { October, 1960: Superficial keratectomy } \\
\text { Contact lenses } \\
\text { Epilation } \\
\text { Electrolysis }\end{array}$ & $\begin{array}{l}\text { Subjective tests unreliable } \\
\text { With } 3 / 60 \text { he gets about without } \\
\text { difficulty }\end{array}$ & $\begin{array}{l}\text { Vascularization after keratectomy } 12 \text { years after } \\
\text { original illness } \\
\text { Definite pemphigoid layers over both corneae } \\
500 \text { r. } \beta \text {-irradiation ineffective }\end{array}$ \\
\hline $\begin{array}{l}\text { Superficial keratectomy (L) } \\
\text { Contact lens }\end{array}$ & L Counting fingers & $\begin{array}{l}\text { Re-invasion of cornea by pemphigoid tissue in } \\
1 \text { month } \\
\text { Cystoscopy showed granulation on internal meatus } \\
\text { Intrastromal abscess led to perforation and } \\
\text { secondary glaucoma }\end{array}$ \\
\hline
\end{tabular}

Such inflammation, which is chronic with acute exacerbations, produces an inflammatory exudate which lifts the overlying epithelium into bullae. In the eye these are transient because of the movement of the lids and may result in areas of ulceration. The same inflammatory process will inevitably progress to fibrous repair and shrinkage unless adequate steroid therapy contains it, and this fibrosis will occur in the same site, i.e. sub-epithelial.

\section{Corneal Changes and Importance of Moisture}

What happens in the cornea is less clear. It is commonly believed that corneal changes are secondary, principally, to xerosis; Rycroft (1934) suggested this and it has been quoted and repeated since. Howard (1963) suggested that corneal opacification is secondary to xerosis in Stevens-Johnson syndrome, but later in the same article states that a favourable Schirmer test does not preclude this complication. On the other hand, several authors have noted that bullae may be present on the cornea in cases of ocular pemphigus (Klauder and Cowan, 1942; Gazala, 1959). These would tend to be even more transient than conjunctival bullae which would explain the fact that they are so rarely seen (Fig. 6, p. 39).

Additional evidence indicates that corneal changes are part of the primary pathology:

(a) When superficial keratectomy is performed, an iris repositor can be freely passed 
behind a pre-corneal membrane which is continuous with the superficial conjunctival tissue. This entire layer can be stripped back to the fornices. This was done in Case 10 and the tissue when examined histologically (see above), showed no difference between corneal and conjunctival portions.

(b) A corneal disc from Case 4 showed the following histology:

Thickened epithelium shows epidermoid change. Bowman's membrane has been destroyed and the underlying stroma is fibrosed and shows areas of cellular infiltration.

Admittedly, this is not a very specific picture but it is what one would expect of the primary pathology in this disease process.

(c) Many of these eyes are moist in the presence of gross corneal pathology.

Case 1 exhibited epiphora during a contact lens trial.

Case 3 showed epiphora following a graft, and 3 years later Schirmer's test in this right eye gave $16 \mathrm{~mm}$. after 4 minutes.

Cases 5 (left eye), 10 (right eye), 12, 14, and 16 all showed moisture in the fornices despite gross corneal changes (Fig. 4, p. 39). In all these cases moisture ran off the surface of the eye literally like water off a duck's back. The surface appears to be a non-wettable one, all the patients prefer oily to aqueous drops, and two patients see better when their contact lenses are filled with paroleine.

This is not to say that lack of lacrimal and conjunctival secretion is not a serious complication. It is not enough, however, to keep an eye moist whilst the disease is progressing, although dryness must of course be avoided. Also, in view of the water-repellent properties of this tissue, the best method of retaining moisture-both natural and artificial-would seem to be a flush-fitting contact lens, and the ideal form of moisture of an oily nature.

\section{Value of Steroids}

In a survey of the use of steroids in ophthalmology, Duke-Elder (1951) classified both erythema multiforme and ocular pemphigus as "showing no response" and commented:

"It may be that isolated cases (of ocular pemphigus) respond to systemic treatment but the response appears to be partial and temporary: in general the results of cortisone therapy so far are disappointing".

What then is the position 12 years later?

Klauder and Cowan (1942) reviewed twelve cases of conjunctival shrinkage, none of which had been treated with steroids. A comparison between these cases and those presented here reveals no significant difference in the ultimate clinical picture. In the present series all but five cases were treated with steroids in one form or another early in the disease.

The five cases with an onset in the pre-steroid era show no substantial difference from those which had the benefit of steroids at an earlier stage. It is, of course, difficult to draw conclusions from this, because the cases in our series tend to be severe, and the exact details of earlier treatment are not all known. It is apparent, however, that the mere use of steroids in these diseases is not enough.

Are steroids then of any value in these diseases? Jones (1961) quotes a case of ocular pemphigus in which

"topical steroids were able to suppress the occurrence of ulcerative lesions in the eye over a period of 2 years until death from cancer. They were quite ineffective, however, in preventing shrinkage and symblepharon following previous ulcerations and at times they had to be used at 15-minute intervals". 




Fig. 1.-Ċase 8. Left eye (March, 1958), mucous membrane graft in upper fornix. Perception of light.

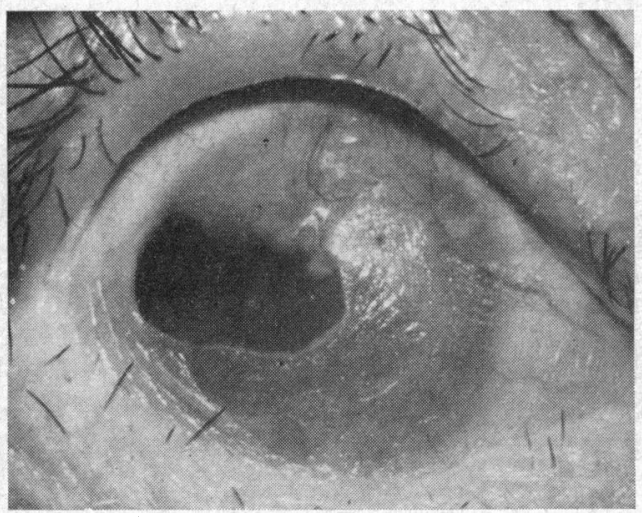

FIG. 2.-Case 8. Left eye (June, 1961), with contact lens in place, showing how lens retains moisture and protects against trichiasis. Visual acuity $6 / 36$.



FIG. 3.-Case 14. Right eye, showing a window of reasonably clear cornea spared by the disease. Visual acuity with contact lens 6/24.

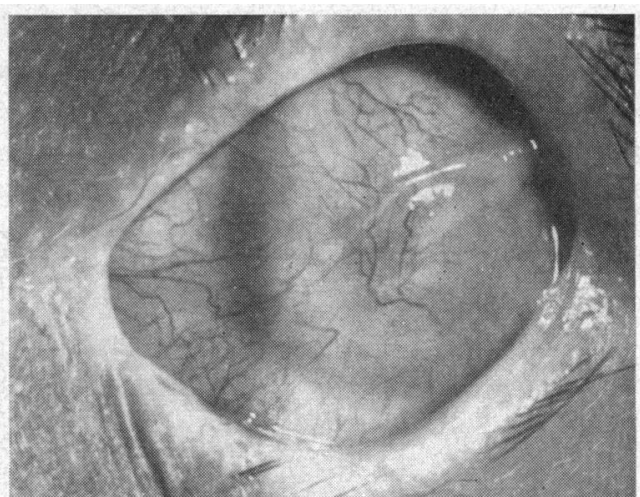

FIG. 4.-Case 5. Left eye, showing extensive fibrous tissue in the presence of moisture. No tear substitutes necessary.

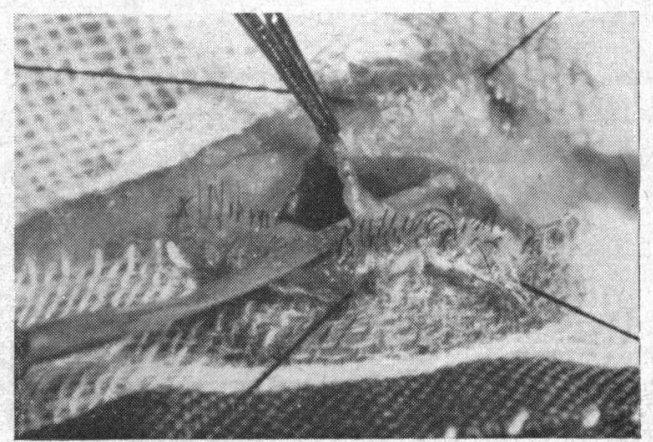

FIG. 5.-Distinct plane behind layer of fibrous tissue.



Fig. 6.-Conjunctival bulla in a case of ocular pemphigus. 
In this series the use of hourly steroid drops in combination with systemic steroids in dosages of $30-35 \mathrm{mg}$. prednisolone has been of definite value in acute episodes and to cover the re-activation caused by surgery. It seems, therefore, that there must be saturation with steroids if they are to be at all effective, and they are, unfortunately, the only definite therapeutic weapon available.

\section{Corneal Grafting}

If this procedure were successful a lamellar graft would afford an ideal method of obtaining a good visual result. The corneal opacification is always superficial and the opaque tissue strips easily to reveal a clear cornea. Eight lamellar and four penetrating keratoplasties have been performed in five cases $(1,2,3,4,8)$, but unfortunately in none of them has the cornea remained clear. In addition, Case 15 had had an unsuccessful lamellar graft before coming to this hospital.

In all the cases observed intense vascularization soon involved the graft and in time it assumed the characteristics of the host cornea. Intense steroid therapy, the constant use of wetting agents, cautery-peritomy, and beta radiation have all failed to check this process.

\section{Fornix Reconstruction}

The primary objects of fornix surgery in these cases are to allow lid closure and the retention of contact lenses. Mucous membrane grafts are rarely successful. Cases 4 and 8 had such grafts at this unit, and Cases 8 and 11 elsewhere. These grafts tend to become vascularized and to undergo contracture. A van Milligan type of mucous membrane graft to the lid margin in Case 7 suffered the same fate. This is in keeping with the findings of Gazala (1959). It must be borne in mind that in ocular pemphigus the graft is of pemphigoid or potentially pemphigoid tissue. The most successful result was obtained in Case 8 -one of erythema multiforme exudativum (Fig. 1, p. 39).

In keeping with the principle of employing a minimum amount of surgery, the standard procedure used is a simple incision at the site of the fornix and the insertion of a Walser shell. An isolated symblepharon is dealt with in the same way. At times the tissue is stripped from the fornix and sutured in placs as well as using a shell.

Even this amount of surgery should not be attempted while the disease is in an active phase and in all cases surgery should be covered with intensive corticosteroid therapy. For this reason the Walser shell is ideal in that its large perforations allow the continuance of topical steroids. Some contracture always follows surgery, but an adequate fornix is usually retained and this procedure, if it must be repeated, involves a minimum of mutilation.

Case 11 showed further contracture 3 months after surgery and contact lenses were extruded presumably because of reactivity of the disease, but Cases 1, 2, 6, and 14 all required fornix surgery and subsequently wore contact lenses with comfort.

\section{Transposition of the Parotid Duct}

This procedure has not been employed, though there is no doubt that a successful anastomosis between Stenson's duct and the conjunctival sac will result in a moist eye 
-indeed the problem is often how to reduce the copious flow (Bennett and Bailey, 1957). Strampelli (1958) concluded that it was not effective even though the eye was moist. In view of the apparently non-wettable surface of many of the affected eyes, the problem is not only one of getting moisture to the eye but also of retaining it.

\section{Lid Surgery}

Many of these cases show distortion of the lids, particularly entropion resulting in trichiasis. Any procedure to evert the entropion should avoid the conjunctival surface of the lid and the one favoured is transcutaneous linear tarsectomy. The difficulty here is that one is not attempting to evert a lax or even a spastic lid but one which is held in place by strong implacable fibrous tissue. As previously mentioned, a van Milligan type of mucous membrane graft was employed in one case but without success.

Because of these difficulties electrolysis of the lashes is often as rewarding as more refined plastic procedures.

\section{Occlusion of the Puncta}

This will help to conserve moisture, both natural and artificial, and is especially valuable in the earlier stages of the disease in a drying eye. However, late in the disease the puncta are usually occluded by fibrous tissue, or are no longer able to drain fluid because of distortion of the lids.

\section{Contact Lenses}

These afford a great advance, both optical and therapeutic. They improve visual acuity, protect the globe, particularly against trichiasis, and retain moisture.

The problem of moisture has already been considered. The difficulty in everting such lids as these has been mentioned - if a contact lens can be worn for long periods it gives excellent protection from the lashes and lid margins.

Nine of our series achieved an improvement in visual acuity with contact lenses either alone or in combination with surgery and have tolerated these lenses well (Cases 1, 2, 6, 8, 9, 10, 12, 13, and 14). In some cases the improvement has been dramatic. Case 8 , who was on the Blind Register with a visual acuity of perception of light, now sees $6 / 36$ with a contact lens (Fig. 2, p. 39). Case 2 improved from hand movements to 6/36-6/24. Even less dramatic improvement can be very rewarding, as in Case 10 who improved from perception of light and hand movements at 1 foot to counting fingers at $\mathbf{3}$ feet, which enables her to move about her house freely and has given her a measure of independence in her old age. A 13-year-old child (Case 12) can now read N8 print.

Not all patients tolerate contact lenses. According to Ridley (1961) they cannot be fitted in an active phase, nor is it usual for those with good vision to tolerate them. This has been borne out in the present series, although two patients $(9,14)$ with good visual acuity in one eye do obtain binocular vision by this means.

Before contemplating surgery, as in other forms of corneal disease, these patients should have a contact lens trial and it is worth filling the lens with oily as well as aqueous solutions. For example, Case 13 presented with a visual acuity of counting 
fingers in each eye, and with contact lenses improved to 6/24-6/24, binocular vision $6 / 18$.

All this represents an enormous improvement in the prognosis for these patients, since in preceding studies the possibility of improvement in vision was seldom entertained. For example, Friede (1951) wrote: "It is possible to preserve the eye, after which measures to improve sight might be considered".

\section{Superficial Keratectomy}

In all these cases the opacification is superficial and a distinct plane exists behind it (Fig. 5, p. 39). Indeed, in advanced cases, the eye may move behind the membrane. This superficial tissue is readily stripped off the remaining cornea which is usually dramatically clear. Bleeding is then stopped with a cautery and a Walser shell is put in place. Thus the technique is simple, though where adhesions exist between the membrane and the deeper cornea, dissection is necessary.

However, as has been emphasized already, this tissue reforms in every case, though it need not necessarily prejudice a good visual result. Cases 1, 6, 8, 10, and 14 (left eye) all obtained an improvement in visual acuity with contact lenses after superficial keratectomy. Fig. 3 (p. 39) shows the right eye of Case 14.

In Case 10 the visual acuity with contact lens was 6/60-6/60 before bilateral superficial keratectomy. This was followed by intensive corticosteroid therapy-at one stage prednisolone $50 \mathrm{mg}$./day - and a visual acuity of $6 / 9$ in the right eye with contact lens resulted.

Similarly Case 14, whose pre-operative vision in the left eye was hand movements, subsequently achieved $6 / 18$ with contact lenses despite a further overgrowth of the cornea. Here again, intensive topical steroids were used, and in this case there is every reason to believe that the disease was burnt out at the time of operation.

In patients with very poor vision who are not improved with contact lenses it is reasonable to attempt superficial keratectomy. This should not be done until the eye has been quiet for some time. It is then preferable to operate on only one eye, and surgery should be followed by intensive steroid therapy, particularly topical drops. In such cases, the membrane which reforms may be less irregular and less opaque and allow better vision.

In addition, at operation, or in the ensuing days, it is possible to examine the lens and the red reflex, for it must be borne in mind that many of these cases, particularly in the ocular pemphigus group, have cataract.

\section{Summary}

The condition originally known as "essential shrinkage of the conjunctiva" is discussed and sixteen severe cases are analysed.

As a basis for determining and assessing a rational method of treatment, the causation, course, and pathology are considered.

The modern treatment of this condition is discussed with reference to the value of steroids, contact lenses, and surgery. With such treatment the prognosis for these patients is considerably improved. 
I am much indebted to Sir Benjamin Rycroft who consistently encouraged me in this work, and to other members of the Corneo-Plastic Unit, East Grinstead, who offered helpful suggestions and criticisms.

I should also like to thank Mr. Gordon Clementson and the Photographic Department at the Queen Victoria Hospital, East Grinstead, for the photographs.

\section{REFERENCES}

Bennetr, J. E., and Bailey, A. L. (1957). A.M.A. Arch. Ophthal., 58, 372.

Borrie, P., and Jones, B. (1959). Proc. roy. Soc. Med., 52, 553.

Church, R. E., and Sneddon, I. B. (1953). Brit. J. Derm., 65, 235.

CivatTe, A. (1949). Arch. belg. Derm. Syph., 5, 273.

COOPER, WHITE (1857-59). Roy. Lond. ophthal. Hosp. Rep., $1,155$.

Duke-Elder, S. (1951). Brit. J. Ophthal., 35, 637.

Franke, E. (1900). "Der Pemphigus und die essentielle Schrumpfung der Bindehaut des Auges". Bergmann, Wiesbaden.

FRIEDE, R. (1951). v. Graefes Arch. Ophthal., 151, 574.

FuCHS, E. (1892). " "Text-Book of Ophthalmology", trans. A. Duane. Appleton, New York.

GaZALA, J. R. (1959). Amer. J. Ophthal., 48, 355.

HANSEN, E. W. (1950). Trans. Amer. ophthal. Soc., 48, 395.

HeBra, F. (1866). "On Diseases of the Skin". New Sydenham Society, London.

HowaRd, G. M. (1963). Amer. J. Ophthal., 55, 893.

Jones, B. R. (1961). Proc. roy. Soc. Med., 54, 109.

Klauder, J. V. (1959). Arch. Derm., 80, 515. and Cowan, A. (1942). Amer. J. Ophthal., 25, 643.

KRIES, N. von (1878). v. Graefes Arch. Ophthal., 24, pt 1., 157.

LeVER, W. F. (1951). Arch. Derm. Syph., 64, 727.

and TALBOTT, J. H. (1942). Arch. Derm. Syph. (Chicago), 46, 348.

LoRTAT-JACOB, R. (1958). Brit. J. Derm., 70, 361.

RIDLEY, F. (1961). Proc. roy. Soc. Med., 54, 110.

RYCROFT, B. W. (1934). Brit. J. Ophthal., 18, 571.

SNEDDON, I. B. (1961). Proc. roy. Soc. Med., 54, 107.

Stevens, A. M., and Johnson, F. C. (1922). Amer. J. Dis. Child., 24, 526.

Strampelli, B. (1958). Boll. Oculist., 37, 89.

Thоsт, A. (1919). Dtsch. med. Wschr., 45, 477.

WolfF, J. E. (1949). Brit. J. Ophthal., 33, 110. 